\title{
PENGARUH KOMUNIKASI CAMAT TERHADAP PENINGKATAN KINERJA APARAT DI KANTOR CAMAT MOUTONG KABUPATEN PARIGI MOUTONG
}

\author{
Sofyan Alhadar \\ Sekolah Tinggi Ilmu Administrasi Bina Taruna Gorontalo \\ alhadsof21@gmail.com
}

\begin{abstract}
ABSTRAK
Pelaksanaa penelitian ini didasarkan pada rumusan masalah yakni seberapa besar Pengaruh Komunikasi Camat terhadap Peningkatan Kinerja Aparat Di Kantor Camat Moutong Kabupaten Parigi Moutong. Berdasarkan rumusan masalah, maka manfaat yang diharapkan dari hasil penelitian ini adalah sebagai bahan masukan bagi Aparat di Kantor Camat Moutong Kabupaten Parigi Moutong dalam rangka Peningkatan kinerja Aparat. Metode yang digunkan dalam penelitian ini adalah metode kuantitatif. Variabel penelitian ini terdiri dari variabel Komunikasi Camat (X) dan Peningkatan Kinerja Aparat (Y). Teknik pengumpulan data yang digunakan adalah observasi, Dokumentasi, Kuesioner/angket. Hasil Penelitian menunjukan bahwa komunikasi camat berpengaruh positif dan signifikan terhadap peningkatan kinerja aparat di Kantor Kecamatan Moutong Kabupaten Parigi Moutong dengan besar pengaruh yakni 72,1\%. Maka dari koefisien positif menunjukan bahwa semakin baik komunikasi camat memberikan dampak yang baik dalam peningkatan kinerja aparat. Dengan kata lain semakin efektif tingkat komunikasi camat yang diterapkan dalam kepemimpinannya maka akan terjadi peningkatan kinerja aparat yang dikarenakan komunikasi camat yang baik membuat kondisi dan keadaan lingkungan kerja dalam suatu instansi akan semakin kondusif sehinggga aparat di Kantor Kecamatan Moutong Kabupaten Parigi Moutong akan bekerja dengan optimal yang akhirnya mampu mencapai visi, misi dan tujuan kantor Kecamatan. Maka dari itu dalam upaya untuk meningkatkan kinerja sebaiknya pimpinan terus membeirkan arahan kepada pegawai atau aparat di Kantor Kecamatan terutama disiplin dalam menjalankan tugas dan tanggung jawabnya, disamping itu perlu adanya instruksi yang jelas dan sanksi yang tegas kepada pegawai agar hasil pekerjaanya berjalan dengan baik.
\end{abstract}

Kata Kunci: Komunikasi; Kinerja; Aparat

\section{ABSTRACT}

The implementation of this research is based on the formulation of the problem, namely how much influence the subdistrict head communication has on improving the performance of officials in the office of the Camat of Moutong, Parigi Moutong Regency. Based on the formulation of the problem, the expected benefits from the results of this study are as input for the Apparatus in the Office of the Camat of Moutong Parigi Moutong Regency to improve the performance of the Apparatus. The method used in this study is quantitative. The variables of this study consisted of the 
Communication Head of Sub-District $(X)$ and Performance Improvement variables $(Y)$. Data collection techniques used are observation, documentation, questionnaire / questionnaire. The results of the study showed that sub-district communication had a positive and significant effect on improving the performance of officers in the Moutong District Office of Parigi Moutong Regency with a large influence of $72.1 \%$. The meaning of the positive coefficient shows that the better communication of the subdistrict head has a good impact on improving the performance of the apparatus. In other words, the more effective the level of communication of the subdistrict head that is applied in his leadership, there will be an increase in the performance of the officers because the sub-district communication is good to make the conditions and conditions of work environment in an institution conducive so that the officers in the Moutong District Office Parigi Moutong finally able to achieve the vision, mission and objectives of the District office.

Keywords: Communication; Apparatus; Performance

\section{PENDAHULUAN}

Undang-Undang Nomor 32 Tahun 2004 sebagai penganti Undang-Undang Nomor 23 Tahun 2014 tentang pemerintah daerah adalah mengenai syarat pembentukan kecamatan, kedudukan, pengklasifikasian, tugas pokok dan fungsi kecamatan yang sebelumnya merupakan perangkat wilayah dalam kerangka asas dekonsentrasi, berubah status menjadi perangkat daerah dalam kerangka asas desentralisasi. Kecamatan dipimpin oleh seorang camat yang dalam tugasnya memperoleh pelimpahan sebagian wewenang bupati atau walikota untuk menangani sebagian urusan otonomi daerah.

Implementasi kebijakan otonomi daerah telah mendorong terjadinya perubahan, baik secara struktural, fungsional maupun kultural dalam tatanan penyelenggaraan pemerintahan daerah. Salah satu perubahan yang sangat esensial yaitu menyangkut kedudukan, tugas pokok dan fungsi kecamatan yang sebelumnya merupakan perangkat wilayah dalam kerangka asas dekonstralisasi, berubah statusnya menjadi perangkat dearah dalam kerangka asas desentralisasi. Sebagai perangkat daerah, camat dalam menjalankan tugasnya mendapat pelimpahan kewenangan dan bertanggung jawab kepada bupati/walikota.

Camat sebagai perangkat daerah juga mempunyai kekhsusan dibandingkan dengan perangkat daerah lainnya dalam pelaksanaan tugas pokok dan fungsinya untuk mendukung pelaksanaan asas desentralisasi. Kekhususan tersebut yaitu adanya suatu kewajiban mengintegrasikan nilai-nilai sosiokultural, menciptakan stabilitas dalam dinamika politik, ekonomi dan budaya, mengupayakan mewujutkan 
ketentraman dan ketertiban wilayah sebagai perwujudan kesejahtraan rakyat dan masyarakat dalam kerangka membangun integritas kesatuan wilayah.

Dalam hal ini camat dapat menjembatani program-program pemerintah untuk meningkatkan kemampuan dan pemberian wewenang secara proporsional sehingga dapat menentukan baik-buruknya kinerja pemerintah Kecamatan. Sebagai mana salah satunya keberadaan komunikasi sangat penting dalam meningkatan kinerja aparat membutuhkan kemampuan baik dalam pencapaian hasil pelaksanaan tugas maupun dalam kegiatan pengelolaan kebijakan yang harus dilakukan pemerintah.

Untuk itu Dalam sebuah organisasi suatu komunikasi sangat diperlukan Tanpa komunikasi suatu proses kerja akan sangat sulit untuk dijalankan, Komunikasi merupakan suatu proses penyampaian informasi dimana informasi itu berupa ide pesan atau gagasan pikiran yang ada dari satu pihak kepihak yang lain Pada umumnya komunikasi dilakukan secara lisan atau verbal yang dapat dimengerti oleh keduanya.

Namun kenyataanya yang terdapat dikantor camat Moutong Kabupaten Parigi Moutong bahwa kinerja aparat belum sesuai harapan dikarnakan komunikasi antara aparat dan camat belum optimal, sehingga dapat berpengaruh terhadap peningkatan kinerja aparat. Pada dasarnya berjalannya roda pemerintah sangat ditunjang dari kinerja aparat oleh karena itu, dituntut adanya komunikasi antara aparat dan camat untuk meningkatkan dan menghasilkan kinerja yang maksimal. Di samping itu tidak menuntut kemungkinan masi kurangnya informasi-informasi yang disampaikan camat kepada aparat yang mana informasi tersebut berkaitan dengan pekerjaan ataupun kebutuhan yang direncanakan. selain itu juga daya tarik camat untuk mempengaruhi aparat ataupun proses penyampaian pesan dengan cara membujuk aparat masi kurang yang mana ketaatan aparat dalam menyelesaikan pekerjaan masi menunda-nunda sehingga memperlambat pekerjaan. Dalam kaitan ini dikarenakan kurang tegasnya camat dalam melakukan tindakan yang mengandung sanksi terhadap aparat yang tidak disiplin dalam pekerjaan. Berkaitan dengan kepemimpinan camat untuk meningkatkan kinerja aparat di Kantor Camat Moutong masih terdapat beberapa kendala di antaranya, sumber daya manusia yang berkaitan dengan daya pikir yang dimiliki oleh perangkat baik yang Non PNS maupun yang sebagai Pegawai Negeri Sipil sehingga berpengaruh pada pekerjaan yang kurang baik dan kurang kreatifitas dalam kerja yang dapat menciptakan iklim kerja yang mendukung bagi terciptanya kinerja yang baik. Dari permasalahan inilah maka peran camat 
sangatlah penting untuk meningkatkan kinerja aparat sehingga apa yang menjadi tuntutan dalam meningkatkan kinerja dapat diciptakan dan mencapai tujuan yang dapat diharapkan.

Di kantor camat moutong kabupaten parigi moutong, menurut pengamatan peneliti bahwa masih banyaknya tugas yang tidak terselesaikan akibat komunikasi camat yang kurang efektif, sehingga aparat mengalami kesulitan untuk mendapatkan informasi tersebut. Yang mana sebagai salah satu unit kerja untuk membantu aparat dalam menyelesaikan pekerjaan. Selain itu juga masih kurangnya daya tarik camat dalam mempengaruhi aparat sehingga memperlambat pekerjaan. Ini dikarenakan masih kurang tegasnya camat dalam memerintahkan aparat untuk menyelesaikan pekerjaan sehingga dapat berpengaruh terhadap peningkatan kinerja aparat. Oleh karena itu semakin baik komunikasi yang dimiliki oleh camat semakin meningkat kinerja aparat.

\section{PERMASALAHAN}

Berdasarkan latar belakang yang telah dikemukan tersebut, maka rumusan masalah dalam penelitian ini adalah bagaimana Pengaruh Komunikasi Camat terhadap Peningkatan Kinerja Aparat Di Kantor Camat Moutong Kabupaten Parigi Moutong?

\section{Tujuan Penelitian}

Adapun tujuan penelitian ini adalah untuk mengetahui Pengaruh Komunikasi Camat terhadap Peningkatan Kinerja Aparat Di Kantor Camat Moutong Kabupaten Parigi Moutong

\section{Fokus Penelitian}

Penelitian ini difokuskan pada:

\section{Komunikasi}

Yang dimaksud dengan komunikasi dalam penelitian ini adalah komunikasi antara camat dan aparatnya harus terus dijalin dengan baik agar tugas-tugas yang dibebankan selesai pada waktunya.

\section{Kinerja}

Yang dimaksud dengan kinerja dalam penelitian ini adalah peran camat dalam meningkatkan kinerja aparatnya yang harus terus diciptakan agar aparat dapat bekerja dengan lebih baik

\section{Lingkungan Kerja}

Yang dimaksud dengan lingkungan kerja dalam penelitian ini adalah bahwa camat harus menciptakan lingkungan kerja yang baik agar aparatnya semangat dalam menjalankan tugas.

\section{METODE PENELITIAN}

Jenis penelitian ini adalah penelitian terapan yang menggunakan metode survei dengan pendekatan kuantitatif yang bertujuan menerapkan, menguji dan mengevaluasi kemampuan suatu teori yang diterapkan untuk memecahkan masalah-masalah praktis. 
Variabel penelitian adalah suatu atribut atau sifat dari orang, obyek atau kegiatan yang mempunyai variasi tertentu yang ditetapkan untuk dipelajari dan ditarik kesimpulannya ( Sugiyono, 2011:28). Di dalam penelitian ini terdapat dua macam variabel, yaitu variabel bebas (independent variabel) serta variabel terikat (dependent variable).

Pada penelitian ini variabel independen $\mathrm{X}$ adalah pengaruh komunikasi camat dan variabel dependen $\mathrm{Y}$ adalah terhadap peningkatan kinerja aparat di kantor camat moutong.

Sumber data yang diperoleh sehubungan dengan penelitian ini adalah: (1) Data primer adalah Data primer yaitu data yang diperoleh dari sumber dan bersifat mentah atau belum diolah (Wijaya, 2013:19). Data ini diperoleh dari pembagian kuesioner kepada responden dengan tujuan untuk mengetahui pengaruh komunikasi camat terhadap peningkatan kinerja aparat di kantor camat Moutong Kabupaten Parigi Moutong; (2) Data sekunder adalah Data sekunder adalah data yang diperoleh dari sumber yang menerbitkan dan bersifat siap pakai (Wijaya, 2013:19). Dalam penelitian ini, data sekunder diperoleh dari berbagai bahan pustaka, baik berupa buku, jurnal-jurnal dan dokumen lainnya yang ada hubungannya dengan materi kajian.

Untuk pengumpulan data yang dilakukan pada penelitian ini adalah:
Observasi adalah tehnik pengumpulan data dengan cara melakukan pengamatan atas obyek dan subyek yang diteliti.

Dokumentasi adalah tehnik pengumpulan data dengan cara pencatatan data sekunder yang tersedia di tempat penelitian antara lain berupa data statistic, guna melengkapi data yang terkumpul melalui observasi dan wawancara.

Survey dengan kuesioner/angket

kuesioner merupakan teknik pengumpulan data yang dilakukan dengan cara memberu seperangkat pertanyaan atau pernyataan tertulis kepada responden untuk dijawabnya.

\section{HASIL PENELITIAN DAN PEMBAHASAN}

Pembahasan penelitian mengenai pengaruh komunikasi camat terhadap peningkatan kinerja aparat di Kantor Kecamatan Moutong Kabupaten Parigi Moutong tidak lepas dari hasil analisis regresi sederhaan yang dilakukan dimana ditemukan bahwa rumus persamaan regresi yakni $\hat{Y}=4,830+$ 0,828X. Dimana dapat diakatakan bahwa apabila tidak terdapat pengaruh dari komunikasi camat, maka Peningkatan kinerja aparat bernilai konstan yakni sebesar 4,830 satuan. Nilai Koefisien Regresi Variabel X (Komunikasi camat) sebesar 0,828, menunjukan setiap perubahan variabel komunikasi camat sebesar 1 satuan akan mempengaruhi Peningkatan kinerja 
aparat di Kantor Kecamatan Moutong Kabupaten Parigi Moutong sebesar 0,828 kali satuan.

Hasil ini menunjukan bahwa komunikasi menjadi hal yang urgen dalam meningkatkan kinerja dari pegawai. Logahan dan Putri (2013) bahwa Keberhasilan komunikasi menjadi tanggung jawab para pihak yang berkomunikasi. Komunikasi antarpribadi sangat potensial untuk memengaruhi atau membujuk orang lain, karena kita dapat menggunakan alat indera (penglihatan, pendengaran, sentuhan, penciuman, pengecap) untuk mempertinggi daya bujuk pesan kita. Sebagai komunikasi yang paling lengkap dan paling sempurna, komunikasi antarpribadi berperan penting hingga kapan pun, selama manusia masih memiliki emosi. Salah satu teori komunikasi antarpribadi yang digunakan dalam penelitian ini adalah Teori Pertukaran Sosial (Social Exchange Theory) dari Thibaut dan Kelley. Teori pertukaran sosial didasarkan pada ide bahwa orang memandang hubungan mereka dalam konteks ekonomi. Mereka menghitung pengorbanan dan membandingkannya dengan penghargaan yang didapatkan dengan meneruskan hubungan itu. Pengorbanan (cost) adalah elemen dari sebuah hubungan yang memiliki nilai negatif bagi seseorang. Sedangkan penghargaan (rewards) adalah elemenelemen dalam sebuah hubungan yang memiliki nilai positif.
Sehingga Dalam organisasi komunikasi memegang peranan yang penting karena komunikasi merupakan penggerak organisasi dimana tujuan organisasi mustahil atau sulit dicapai tanpa adanya komunikasi. Organisasi terbentuk karena adanya kesamaan tujuan yang dimiliki tiap anggota. Orang yang tertarik untuk bergabung dalam suatu organisasi memiliki alasan yang beragam. Ada yang karena alasan profit, tuntutan profesi, penyebaran ideologi maupun pemenuhan kebutuhan sosial. Organisasi juga dapat dikatakan sebagai sarana dimana manajemen mengoordinasikan sumber bahan dan sumber daya manusia melalui pola struktur formal dari tugas-tugas dan wewenang. Budaya organisasi terbentuk melalui interaksi antaranggota. Bahkan bisa dikatakan, ibarat organisasi adalah tubuh makhluk hidup maka komunikasi adalah darah yang mengalir dalam tubuh organisasi tersebut.

Sebagaimana dikatakan oleh Suwarto (2014) bahwa Komunikasi yang dijalin oleh anggota dalam hubungan kerja bertujuan untuk meningkatkan hubungan antar individu dan antar unit kerja atau organisasi dan mendorong semangat kerja, sehingga terlihat pentingnya komunikasi untuk meningkatkan keberhasilan pelayanan. komunikasi efektif antara atasan dan bawahan sangat berpengaruh terhadap kepuasan kerja pegawai. Setiap pegawai dalam organisasi dituntut untuk memberikan kontribusi positif melalui 
kinerja yang baik, mengingat kinerja organisasi tergantung pada kinerja pegawainya. Kinerja adalah tingkat terhadapnya para pegawai mencapai persyaratan pekerjaan secara efisien dan efektif. kinerja pegawai merupakan prestasi kerja, yakni perbandingan antara hasil kerja yang dapat dilihat secara nyata dengan standar kerja yang telah ditetapkan organisasi. Kinerja yaitu suatu hasil yang dicapai oleh pegawai dalam pekerjaanya menurut kriteria tertentu yang berlaku untuk suatu pekerjaan.

Menurut Prabasari (2012), semakin lancar dan cepat serta efektif komunikasi yang dijalin akan semakin cepat pula dapat terbinanya hubungan kerja yang baik. Komunikasi yang baik dan efektif diharapkan menghadirkan motivasi kerja yang semakin meningkat bagi semua pegawai. Dengan motivasi kerja yang semakin meningkat disiplin kerja juga diharapkan semakin baik. Pada akhirnya semua diharapkan bermuara pada peningkatan kinerja aparatur yang berdampak pada peningkatan kepuasan layanan pada masyarakat luas. Salah satu upaya yang dapat dilakukan oleh manajemen untuk meningkatkan kinerja organisasi adalah dengan memberikan motivasi bagi para pegawai.

Hal ini dibuktikan dari pengujian hipotesis bahwa komunikasi camat berpengaruh positif dan signifikan terhadap peningkatan kinerja aparat di Kantor Kecamatan Moutong Kabupaten
Parigi Moutong. Makna dari koefisien positif menunjukan bahwa semakin baik komunikasi camat memberikan dampak yang baik dalam peningkatan kinerja aparat. Dengan kata lain semakin efektif tingkat komunikasi camat yang diterapkan dalam kepemimpinannya maka akan terjadi peningkatan kinerja aparat yang dikarenakan komunikasi camat yang baik membuat kondisi dan keadaan lingkungan kerja dalam suatu instansi akan semamin kondusif sehinggga aparat di Kantor Kecamatan Moutong Kabupaten Parigi Moutong akan bekerja dengan optimal yang akhirnya mampu mencapai visi, misi dan tujuan kantor Kecamatan.

Nilai koefisien determinasi $R$ Square sebesar 0,721. Nilai ini menunjukan bahwa sebesar $72,1 \%$ variabilitas Peningkatan kinerja aparat di Kantor Kecamatan Moutong Kabupaten Parigi Moutong dapat dijelaskan oleh komunikasi camat, sedangkan sisanya sebesar $27,9 \%$ dapat dijelaskan oleh variabel lain yang tidak diteliti dalam penelitian in seperti variabel stres kerja, kompensasi, penempatan kerja, budaya organisasi, motivasi kerja, disiplin kerja, kompetensi pegawai serta variabel lainnya.

Adanya hasil signifikan tersebut maka dalam upaya untuk meningkatkan kinerja sebaiknya pimpinan terus membeirkan arahan kepada pegawai atau aparat di Kantor Kecamatan terutama untuk berlaku disiplin dalam 
menjalankan tugas dan tanggung jawabnya, disamping itu perlu adanya instruksi yang jelas dan sanksi yang tegas kepada pegawai agar hasil pekerjaanya diupayakan oleh pegawai berjalan dengan baik. Serta pimpinan terus mengasah kemampuan kepemimpinan dengan menerapkan berbagai gaya kepemimpinan yang baik dan sesuai serta mampu bersikap luwes dan fleksibel kepada pegawai agar koordinasi dapat terjaga dan pekerjaan menjadi lebih optimal baik pekerjaan sebagai pimpinan maupun pekerjaan dari pegawai.

\section{SIMPULAN}

Berdasarkan penjelasan pada hasil analisis penelitian dan pembahasan maka dapat disimpulkan bahwa komunikasi camat berpengaruh positif dan signifikan terhadap peningkatan kinerja aparat di Kantor Kecamatan Moutong Kabupaten Parigi Moutong.

Maka dari koefisien positif menunjukan bahwa semakin baik komunikasi camat memberikan dampak yang baik dalam peningkatan kinerja aparat. Dengan kata lain semakin efektif tingkat komunikasi camat yang diterapkan dalam kepemimpinannya maka akan terjadi peningkatan kinerja aparat yang dikarenakan komunikasi camat yang baik membuat kondisi dan keadaan lingkungan kerja dalam suatu instansi akan semakin kondusif sehinggga aparat di Kantor Kecamatan Moutong Kabupaten Parigi Moutong akan bekerja dengan optimal yang akhirnya mampu mencapai visi, misi dan tujuan kantor Kecamatan.

Nilai koefisien determinasi $R$ Square sebesar 0,721. Nilai ini menunjukan bahwa sebesar $72,1 \%$ variabilitas Peningkatan kinerja aparat di Kantor Kecamatan Moutong Kabupaten Parigi Moutong dapat dijelaskan oleh komunikasi camat, sedangkan sisanya sebesar $27,9 \%$ dapat dijelaskan oleh variabel lain yang tidak diteliti dalam penelitian in seperti variabel stres kerja, kompensasi, penempatan kerja, budaya organisasi, motivasi kerja, disiplin kerja, kompetensi pegawai serta variabel lainnya.

\section{SARAN}

Berdasarkan simpulan tersebut, maka disarankan agar camat sebaiknya terus menjalin komunikasi yang baik yang akan memberikan dampak bagi aparat sehingga dapat meningkatkan kinerja, selain itu lingkungan kerja terus dibina agar membuat kondisi dan keadaan lingkungan kerja semakin kondusif sehinggga aparat di Kantor Kecamatan Moutong Kabupaten Parigi Moutong akan bekerja dengan optimal yang akhirnya mampu mencapai visi, misi dan tujuan kantor Kecamatan.

\section{DAFTAR PUSTAKA}
A.A. Anwar Prabu Mangkunegara, 2011, Evaluasi Kinerja Sumber 
Daya Manusia. Bandung: Refika Aditama

Arikunto, S. 2013. Prosedur Penelitian

Suatu Pendekatan Praktis,

Jakarta: Rineka Cipta

Bungin, Burhan. 2010. Metode

Penelitian Kualitatif. Jakarta:

Rajawali Pers

Cangara, Hafied. 2010, Pengantar Imu

Komunikasi, Jakarta: PT Raja

Grafindo Persada

Drs, Tommy Suprapto, M.S. 2011.

Pengantar Ilmu Komunikasi,

Jakarta: CAPS

Fajar, Marhaeni. 2009. Ilmu

Komunikasi Teori Dan Praktek

Edisi Pertama. Yogyakarta:

Graha Ilmu.

Filippo, Edwin B. 2013. Manajemen

Personalia, Jakarta: PT Gelora

Askara Pratama

Handoko, T.Hani. 2009. Manajemen

Cetakan Dua Puluh. Yogyakarta: PT BPEE.

Hasibuan, Malayu. 2012. Manajemen

Sumber Daya Manusia, Jakarta:

PT. Bumi Aksara

Komala, Lukiati. 2009. Ilmu Komunikasi Perspektif, Proses, Dan Konteks. Bandung: Widya Padjadjaran.

Mulyana, Deddy. 2008. Komunikasi

Efektif Suatu Pendekatan Lintas

Budaya. Bandung: PT Remaja

Pos Dkarya

Marwansyah. 2010. Manajemen Sumber

Daya Manusia Edisi Kedua.

Bandung: Alfabeta
Mardiasmo. 2012. perpajakan, yogyakarta: CV Andi Offset

Mulyana, Deddy. 2009. Ilmu Komunikasi Suatu Pengantar, Bandung: Remaja Posdakarya

-----------, 2008. Komunikasi Efektif Suatu Pendekatan Lintas Budaya, Bandung: PT Remaja Posdakarya

Notoatmodja, Soekidjo. 2010. pengembangan Sumber Daya Manusia. Jakarta: Rineka Cipta

Prawirosentono. 2008. Kebijakan Kinerja Karyawan. Yogyakarta: BPFE.

Ruliana, Poppy. 2014. Komunikasi Organisasi Teori Dan Studi Kasus.Jakarta: PT Raja Grafindo Persada.

Ruslan, Rosady. 2008. Manajemen Publik Relation Dan Media Komunikasi. Jakarta: PT Raja Persada.

S.P, Hasibuan, Malayu. 2013, Manajemen Sumber Daya Manusi. Jakarta: PT Bumi Aksara. Suharsono. 2012. Pengembangan Dasar Organisasi. Jakarta: Atma Jaya

Sunyoto, Danang. 2013. Manajemen Sumber Daya Manusia. Jakarta: PT Buku seru.

Suprapto Tommy. 2011. Pengantar Ilmu Komunikasi Dan Manajemen Dalam Komunikasi. Jakarta: Buku Seru

Sugiyono. 2013. Statistika Untuk Penelitian. Bandung: Alfabetas Trenholm, S Dan Jensen, A. 2009, Interppersonal Communication. 
California: Wadsworth Publising Company

Wirawan. 2009. Efaluasi Kinerja

Sumber Daya Manusia., Jakarta:

Salemba.

Wibowo. 2011. Manajemen Kinerja.

Jakarta: PT Raja Grafindo

Persada.

Widjaja, H.A.W. 2008. Komunikasi

Dan Hubungan Masyarakat.

Jakarta: Bumi Aksara. 